\title{
PENGARUH TEMPERATUR MESOFILIK TERHADAP LAJU ALIRAN BIOGAS DAN UJI NYALA API MENGGUNAKAN BAHAN BAKU LIMBAH KOLAM IKAN GURAME
}

\author{
Dwi Irawan', Kemas Ridhuan² \\ Jurusan Teknik Mesin, Fakultas Teknik, Universitas Muhammadiyah Metro ${ }^{1,2}$ \\ Jl. Ki Hajar Dewantara 15 A Metro, Lampung \\ Email: dwi_irawan12@yahoo.co.id ${ }^{1}$, kmsridhuan@yahoo.co.id ${ }^{2}$
}

\begin{abstract}
The reserve lack of fossil fuels as a source of energy in contrast to increasing the energy demand growth as human populations, especially in indonesia. Biogas as renewable energy environmentally friendly could be one of solutions to current permasalah energy. Biogas produced with the help of bacteria metanogen or metanogenik. Biogas produced by take waste farm will bring value more. Waste management done with better than it can prevent the environmental pollution also provide added value of business cattle or the cultivation of fish. If dirt shaped mud and it is not so levels soon cleared ammonia in the water would rise and can threaten survival ikan-ikan preserved. The purpose of this study is to find influence temperature mesofilik against the rate of flow of biogas and hasill flame biogas. The method do first is preparing equipment for making a series of using drigen biogas, with varying temperature that $30^{\circ} \mathrm{C}$ mesofilik, $35^{\circ} \mathrm{C}, 40^{\circ} \mathrm{C}$. The result showed, the rate of flow of treatment $t 1$ biogas $736,8 \mathrm{ml} / \mathrm{day}$, as for treatment t2 the rate of flow of biogas $774,8 \mathrm{ml} /$ day, and treatment t3 the rate of flow of biogas $748,75 \mathrm{ml} /$ day and potential biogas $1,8719 \mathrm{ml} /$ liters of raw materials with the same pressure on all the treatment 101.570,25 $\mathrm{N} / \mathrm{m}^{2}$. The fiery show results flame blue biogas resulting from all treatment.The result showed treatment temperature impact on the rate of flow of biogas and results flame biogas.
\end{abstract}

Keywords: Temperature, Mesofilik, Biogas

\section{PENDAHULUAN}

Minyak bumi adalah bahan bakar fosil yang tidak dapat diperbaharui, tetapi bahan bakar minyak masih menjadi pilihan utama sehingga akan mengakibatkan menipisnya cadangan minyak bumi. Sementara gas bumi dan energi alternatif lainnya belum dimaksimalkan pemanfaatannya. Cadangan minyak Indonesia hanya tersisa sekitar 9 milliar barel. Apabila terus dikonsumsi tanpa ditemukannya cadangan minyak baru, diperkirakan cadangan minyak yang dimiliki oleh Indonesia akan habis dalam dua dekade mendatang [1].

Berbagai kasus pencemaran lingkungan dan memburuknya kesehatan masyarakat yang terjadi dewasa ini diakibatkan oleh limbah dari berbagai kegiatan industri, rumah sakit, pasar, restoran hingga rumah tangga. Hal ini disebabkan karena penanganan dan pengolahan limbah tersebut belum mendapatkan perhatian serius. Kebanyakan dari limbah tersebut biasanya langsung dibuang tanpa pengolahan terlebih dahulu. Limbah atau kotoran terurai juga dapat menyumbangkan emisi gas rumah kaca yaitu gas metana $\left(\mathrm{CH}_{4}\right)$.

Pengelolaan limbah yang dilakukan dengan baik selain dapat mencegah terjadinya pencemaran lingkungan juga memberikan nilai tambah terhadap usaha ternak [2]. Di Indonesia banyak sekali sentral ikan air tawar, hampir disetiap daerah mempunyai usaha perikanan air tawar, tetapi limbahnya masih belum 
dimanfaatkan dengan baik. Pada umumnya pembuangan limbah kolam akan dilakukan dua - tiga minggu sekali dengan membuang air pada bagian dasar yang merupakan limbah yang berasal dari kotoran ikan (feses) dan sisa pakan. Jika kotoran berbentuk lumpur pekat ini tidak segera dibersihkan maka kadar amonia dalam air kolam akan meningkat dan dapat mengancam kelangsungan hidup ikan-ikan yang dipelihara [3].

Suhu merupakan salah satu parameter yang berpengaruh pada proses dekomposi anaerob bahan organik dan produksi gas. Peningkatan suhu dimaksudkan untuk mempercepat laju perombakan, sehingga menghasilkan gas lebih optimal dan proses perombakan lebih efisien [4]. Ada 3 kondisi suhu pada proses pencernaan anaerobik yaitu, Kondisi psikoprilik bekerja pada rentan $10-18^{0} \mathrm{C}$, Kondisi mesofilik bekerja pada rentan suhu $20-45^{\circ} \mathrm{C}$, dan Kondisi termofilik bekerja pada rentan suhu 50$70^{\circ} \mathrm{C}[5]$.

\section{KAJIAN LITERATUR}

\section{Biogas}

Biogas merupakan campuran antara gas-gas yang dihasilkan dari proses penguraian anaerob (tanpa udara) atau fermentasi dari material organik seperti kotoran hewan, lumpur kotoran, sampah padat atau sampah terurai. Biogas dapat dihasilkan pada hari ke 4-5 sesudah digester terisi penuh dan mencapai puncaknya pada hari ke 20-25 [6]. Dalam proses pembuatan biogas, sumber bahan baku atau limbah yang digunakan akan mempengaruhi kualitas dan kuantitas biogas yang dihasilkan [4]. Proses dekomposisi anaerobik dibantu oleh sejumlah mikroorganisme, terutama bakteri metanogen.

Terdapat tiga kelompok bakteri yang berperan dalam proses pembentukan biogas, [6] yaitu:
1. Kelompok bakteri fermentatif: Steptococci, Bacteriodes, dan beberapa jenis Enterobactericeae

2. Kelompok bakteri asetogenik: Methanobacillus, Desulfovibrio dan sebagainya.

3. Kelompok bakteri metana: Mathanobacterium, Mathanobacillus, Methanosacaria, dan Methanococcus.

Kandungan utama dari biogas adalah gas metana $\left(\mathrm{CH}_{4}\right) 54-70 \%$, karbondioksida $\left(\mathrm{CO}_{2}\right)$ 27-35\%, karbon monoksida (CO) $0,1 \%$, oksigen $\left(\mathrm{O}_{2}\right) 0,1 \%$, nitrogen $(\mathrm{N})$, hidrogen $\left(\mathrm{H}_{2}\right)$ dan hidrogen sulfida $\left(\mathrm{H}_{2} \mathrm{~S}\right)$ [9]. Sedangkan dari sumber lainnya kandungan gas lainnya yang terkandung dalam biogas dapat dilihat pada tabel dibawah ini.

Tabel 1. Komposisi Senyawa Biogas [7].

\begin{tabular}{|c|c|c|}
\hline Senyawa & $\begin{array}{c}\text { Rumus } \\
\text { Kimia }\end{array}$ & Kadar (\%) \\
\hline Metana & $\mathrm{CH}_{4}$ & $50-70$ \\
\hline Karbondioksida & $\mathrm{CO}_{2}$ & $30-40$ \\
\hline Hidrogen & $\mathrm{H}_{2}$ & $5-10$ \\
\hline Nitrogen & $\mathrm{N}_{2}$ & 1,2 \\
\hline Uap air & $\mathrm{H}_{2} \mathrm{O}$ & 0,3 \\
\hline Hidrogen Sulfida & $\mathrm{H}_{2} \mathrm{~S}$ & Sisa \\
\hline
\end{tabular}

Tabel 2. Nilai Kesetaraan Biogas dengan Sumber Energi Lain Tiap $1 \mathrm{~m}^{3}$ [7].

\begin{tabular}{|c|c|c|}
\hline No & Energi Lain & $\begin{array}{c}\text { Nilai } \\
\text { Kesetaraan }\end{array}$ \\
\hline 1 & LPG & $0,46 \mathrm{Kg}$ \\
\hline 2 & Solar & $0,62 \mathrm{Liter}$ \\
\hline 3 & Bensin & $0,52 \mathrm{Liter}$ \\
\hline 4 & $\begin{array}{c}\text { Minyak } \\
\text { Tanah }\end{array}$ & $0,80 \mathrm{Liter}$ \\
\hline 5 & Kayu Bakar & $3,5 \mathrm{Kg}$ \\
\hline 6 & Gas Kota & $1,5 \mathrm{~m}^{3}$ \\
\hline
\end{tabular}




\section{Temperatur}

Pada umumnya terdapat dua kondisi suhu pada proses fermentasi anaerobik, yaitu pada kondisi suhu mesofilik dan kondisi suhu termofilik. Pada kondisi suhu mesofilik, suhu bekerja pada kisaran 28 $45^{\circ} \mathrm{C}$ dengan kondisi suhu optimum 35 $45^{\circ} \mathrm{C}$ sedangkan pada kondisi termofilik suhu bekerja pada kisaran $50-60^{\circ} \mathrm{C}$. Suhu optimal untuk mikroorganisme mesofilik adalah pada angka $35^{\circ} \mathrm{C}$, sedangkan untuk mikroorganisme termofilik adalah pada suhu $55^{\circ} \mathrm{C}$.

Rentan suhu optimal untuk digester di Indonesia adalah pada kisaran $35^{\circ} \mathrm{C}$ [4]. Oleh karena itu perlu pertimbangan dalam pembuatan digester anaerobik karena pada suhu dingin biasanya bakteri lebih lambat berproses sehingga biogas yang dihasilkan mungkin lebih lama [8].

Ada 3 kondisi suhu pada proses pencernaan anaerobik [5], yaitu:

1. Kondisi psikoprilik

Pada kondisi ini suhu digester bekerja pada rentan $10-18^{0} \mathrm{C}$ dan limbah/ sampah cair terdigestifikasi selama 30 - 52 hari.

2. Kondisi mesofilik

Pada kondisi mesofilik suhu digester bekerja pada rentan suhu $20-45^{\circ} \mathrm{C}$, dan sampah/ limbah cair terdigestifikasi selama 18 - 28 hari. Dibandingkan dengan kondisi termofilik, digester pada kondisi mesofilik pengoperasiannya lebih mudah tetapi biogas yang dihasilkan lebih sedikit dan volume digester lebih besar.

3. Kondisi termofilik

Pada kondisi termofilik digester bekerja pada rentan suhu $50-70^{\circ} \mathrm{C}$ dan limbah terdigestifikasi selama $11-17$ hari. Pada kondisi ini biogas yang dihasilkan lebih banyak, tetapi pengoperasiannya rumit dan mahal

\section{Persamaan dalam Pembentukan Biogas}

Persamaan yang dapat digunakan dalam menentukan proses pembentukan biogas dari proses fermentasi limbah pada digester anerobik adalah sebagai berikut:

\section{Persamaan tekanan biogas}

Pada percobaan skala laboratorium, tekanan biogas yang dihasilkan dapat dihitung dengan melihat data pada manometer $\mathrm{U}$ dan menggunakan data tersebut pada persamaan dibawah ini.

$P_{\text {gas }}=P_{a t m}+\rho g h \quad$ [9].

Keterangan:

$P_{g}=$ Tekanan Biogas $\left(\mathrm{N} / \mathrm{m}^{2}\right)$

$P_{a t m}=$ Tekanan udara luar $\left(101.325 \mathrm{~N} / \mathrm{m}^{2}\right)$

$\rho \quad=$ Masa Jenis air $\left(1.000 \mathrm{~kg} / \mathrm{m}^{3}\right)$

$\mathrm{g}=$ Gravitasi $\left(9,81 \mathrm{~m} / \mathrm{s}^{2}\right)$

$\mathrm{h}=$ Perbedaan tinggi air $(\mathrm{m})$

2. Laju aliran produksi biogas perhari

Laju aliran produksi perhari biogas yang dihasilkan dari proses fermentasi anaerob limbah kolam pembesaran ikan gurame merupakan rata-rata hasil biogas yang diproduksi dari subtrat dalam digester selama 25 hari waktu fermentasi. Sehingga untuk mencari laju aliran biogas harian dapat diketahui dengan persamaan sebagai berikut.

$V_{\text {rata-rata harian }}=\frac{V_{\text {total }}}{t}$

Keterangan:

$V_{r}=$ Laju aliran biogas perhari $(\mathrm{ml} /$ hari $)$

$V_{\text {total }}=$ Volume total biogas $(\mathrm{ml})$

$t \quad=$ Lama waktu fermentasi (hari)

3. Potensi biogas limbah kolam pembesaran ikan gurame

Potensi biogas dapat dianalisa dengan melakukan perhitungan matematis yaitu dengan membagi volume total akumulasi biogas yang diproduksi dibagi dengan jumlah volume subtrat dalam digester. Persamaan untuk potensi biogas limbah kolam 
pembesaran ikan gurame dapat dituliskan sebagai berikut.

$$
P_{\text {biogas }}=\frac{V_{\text {total biogas }}}{V_{\text {total subtrat }}}
$$

Keterangan:

$P_{\text {biogas }}=$ Potensi biogas $(\mathrm{ml} /$ liter $(B B))$

$V_{\text {total biogas }}=$ Volume biogas total $(\mathrm{ml})$

$V_{\text {total subrat }}=$ Volume subtrat (liter)

\section{METODE PENELITIAN}

Penelitian ini dilakukan di Laboratorium Teknik Mesin Fakultas Teknik Universitas Muhammadiyah Metro.

Kegiatan penelitian dilakukan dengan menggunakan rancangan percobaan dengan distribusi variabel sebagai berikut :

1. $\mathrm{T} 1$ : perlakuan dengan suhu $30^{\circ} \mathrm{C}$

2. $\mathrm{T} 2$ : perlakuan dengan suhu $35^{\circ} \mathrm{C}$

3. $\mathrm{T} 3$ : perlakuan dengan suhu $40^{\circ} \mathrm{C}$

\section{HASIL DAN PEMBAHASAN}

\section{Laju Aliran Biogas}

Volume biogas tiap hari bisa dilihat pada gambar 2 dibawah ini:

a. Temperature $30^{\circ} \mathrm{C}$

$$
\begin{aligned}
V_{\text {average }} & =\frac{V_{\text {total }}}{t} \\
V_{\text {average }} & =\frac{18.420 \mathrm{ml}}{25 \mathrm{hari}} \\
V_{\text {average }} & =736.8 \mathrm{ml} / \mathrm{hari}
\end{aligned}
$$

b. Subtrat dengan suhu $35^{\circ} \mathrm{C}$

$$
\begin{aligned}
V_{\text {rata-rata harian }} & =\frac{V_{\text {total }}}{t} \\
V_{\text {rata-rata harian }} & =\frac{19.370 \mathrm{ml}}{25 \mathrm{hari}} \\
V_{\text {rata-rata harian }} & =774,8 \mathrm{ml} / \text { hari }
\end{aligned}
$$

c. Subtrat dengan perlakuan suhu $40^{\circ} \mathrm{C}$

$$
\begin{aligned}
V_{\text {rata-rata harian }} & =\frac{V_{\text {total }}}{t} \\
V_{\text {rata-rata harian }} & =\frac{14975 \mathrm{ml}}{20 \text { hari }}
\end{aligned}
$$

$$
V_{\text {rata-rata harian }}=748,75 \mathrm{ml} / \text { hari }
$$

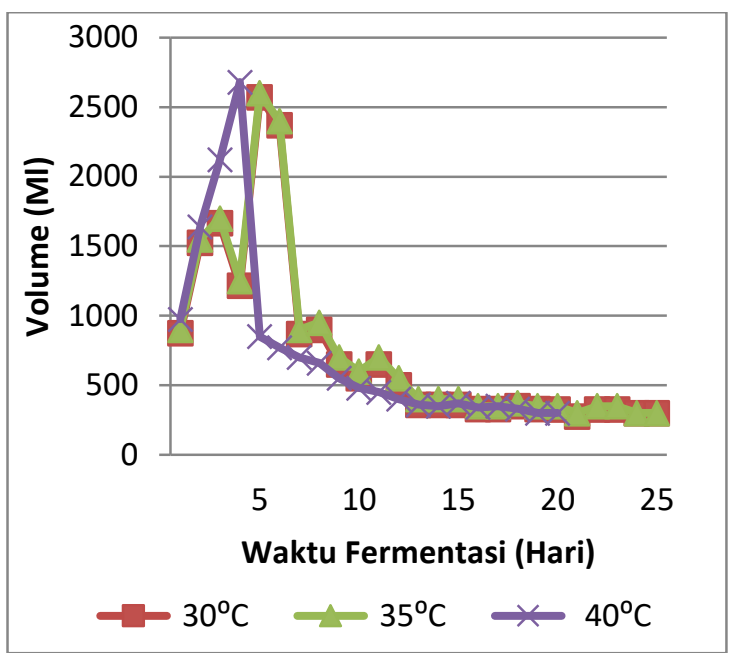

Gambar 1. Grafik Laju aliran biogas

\section{Nyala Api biogas}

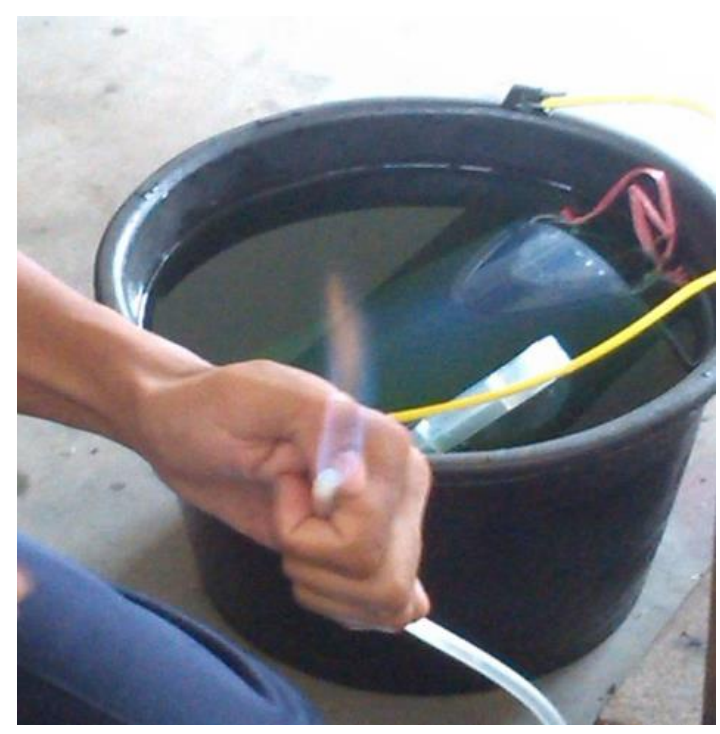

Gambar 2. Nyala api $\mathrm{T} 130^{\circ} \mathrm{C}$.

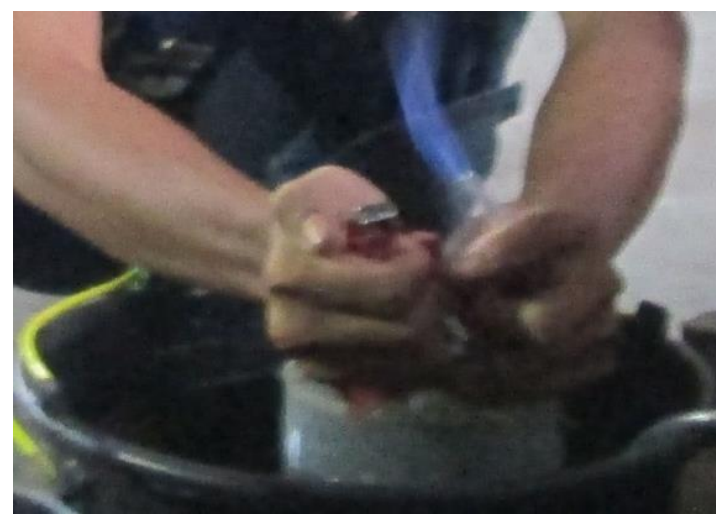

Gambar 3. Nyala Api T2 $35^{\circ} \mathrm{C}$. 


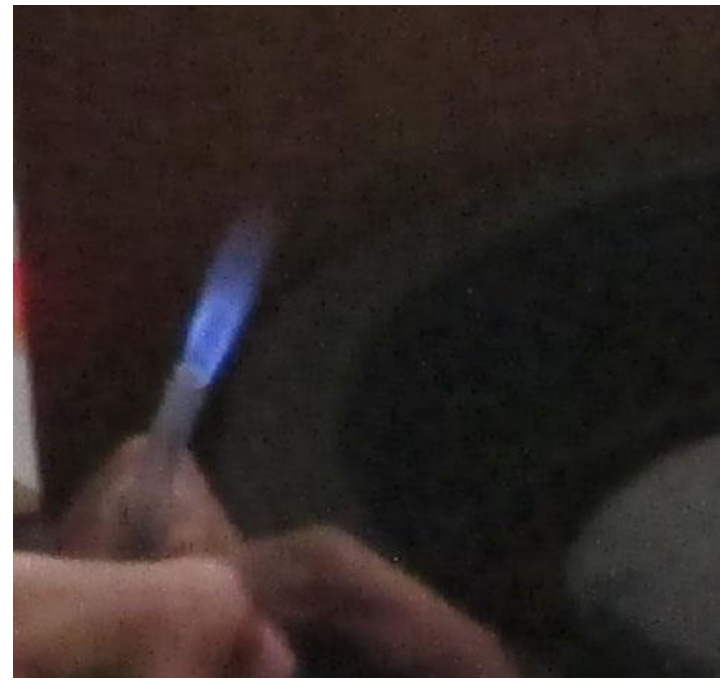

Gambar 4. Nyala Api T3 $40^{\circ} \mathrm{C}$.

Dari ketiga nyala api biogas menunjukkan hasil nyala api biru biogas yang dihasilkan dari semua perlakuan.

\section{KESIMPULAN}

Kesimpulan dari penelitian ini adalah

1. Laju aliran $\mathrm{T} 130^{\circ} \mathrm{C}$ sebesar 736,8 $\mathrm{ml} /$ hari, laju aliran $\mathrm{T} 2 \quad 35^{\circ} \mathrm{C} \quad 774,8$ $\mathrm{ml} /$ hari, laju aliran $\mathrm{T} 3 \quad 40^{\circ} \mathrm{C} \quad 748,8$ $\mathrm{ml} /$ perhari dan potensi $1871,9 \mathrm{ml} / \mathrm{liter}$ pada tekanan biogas yang sama pada semua perlakuan yaitu $101.570,25 \mathrm{~N} / \mathrm{m}^{2}$.

2. Hasil uji nyala menunjukkan bahwa biogas hasil produksi pada semua perlakuan dapat terbakar dengan warna api biru.

\section{REFERENSI}

[1] Contained Energy Indonesia. 2010. Buku Panduan Energi yang Terbarukan. Kementerian Dalam Negeri Republik Indonesia.

[2] Kaharudin dan Farida S. 2010. Petunjuk Praktis Manajemen Umum Limbah Ternak untuk Kompos dan Biogas. Kementerian Pertanian: Balai Pengkajian Teknologi Pertanian NTB.
[3] Sani, Berlin. 2014. Budidaya Ikan Gurami. Yogyakarta: Dafa Publising.

[4] Indarto, Ex, Khori. 2010. Produksi Biogas Limbah Cair Industri Tapioka Melalui Peningkatan Suhu dan Penambahan Urea pada Perombakan Anaerob. Skripsi Jurusan Biologi FMIPA Universitas Sebelas Maret Surakarta.

[5] Waskito, didit. 2011. Analisa Pembangkit Listrik Tenaga Biogas Dengan Pemanfatkan Kotoran Sapi di Kawasan Usaha Peternakan Sapi. Tesis Fakultas Teknik Program Magister Teknik Manajemen Energi dan Ketenagalistrikan UI Salemba.

[6] Irawan, D., \& Khudori, A. (2015). Pengaruh Suhu Anaerobik Terhadap Hasil Biogas Menggunakan Bahan Baku Limbah Kolam Ikan Gurame. TURBO [Jurnal Teknik Mesin], 4(1).

[7] Agustina, Fransiska, 2011. Evaluasi Parameter Produksi Biogas dari Limbah Cair Industri Tapioka dalam Bioreaktor Anaerobik 2 Tahap. Tesis tidak diterbitkan. Semarang: Program Pasca Sarjana Magister Teknik Kimia Universitas Diponegoro Semarang.

[8] Wahyono, Edi Hendras dan Nano Sudarmo. 2012. Biogas Energi Ramah Lingkungan. Bogor : Developing Collaborative Manajement of Cibodas Biosphere Reserve West Java.

[9] Costa, Jaquim Da . 2011. Optimasi Produksi Biogas pada Anaerobic Digester Biogas Type Horizontal Berbahan Baku Kotoran Sapi dengan Pengaturan Suhu dan Pengadukan. Tesis Bidang 
Keahlian Rekayasa Konversi Energi

Program Studi Teknik Mesin

fakultas Teknologi Industri Institut

Teknologi Sepuluh Nopember

Surabaya. 